Tetrahedron Letters

journal homepage: www.elsevier.com

\title{
Asymmetric Synthesis of Structural Analogues of (+)-Clusianone via Enantioselective ACC Alkylation
}

\author{
Michelle R. Garnsey, Maulen M. Uteuliyev and Don M. Coltart* \\ Department of Chemistry, University of Houston, Houston, TX, 77204-5003, U.S.A.
}

ARTICLE INFO

ABSTRACT

Article history:

Received

Revised

Accepted

Available online

Keywords:

ACC ketone alkylation

Asymmetric synthesis

Polycyclic polyprenylated acylphloroglucinols

Viral infection
The asymmetric total synthesis of four structural analogues of $(+)$-clusianone from a common advanced intermediate is described. Asymmetric induction is achieved through the use of enantioselective ACC alkylation, providing the common advanced intermediate with an er of 99:1.
Viral infections are a common and problematic form of disease. As with antibiotics, ${ }^{1}$ current antiviral therapies are becoming less effective due to the development of resistant strains. $^{2}$ Consequently, there is an urgent need for new anti-viral agents. (+)-Clusianone (1) (Figure 1) is a member of a large class of biologically active natural products termed polycyclic polyprenylated acylphloroglucinols (PPAPs). ${ }^{3} \quad(+)$-Clusianone has been shown to possess antiviral activity against both HIV $\left(\mathrm{EC}_{50}=0.020 \pm 0.003 \mu \mathrm{M}\right){ }^{4}$ and Epstein-Barr virus $(17.4 \pm 1.2 \%$ of cells were EBV-EA positive in the presence of $32 \mathrm{nmol}$ of 1). ${ }^{5}$ We recently completed the first asymmetric total synthesis of $(+)$-clusianone ${ }^{6}$ using an enantioselective ketone $\alpha$-alkylation method that we have been developing in our laboratory. ${ }^{7}$ Subsequently, this route was used in the preparation of (-)clusianone as well. ${ }^{8-10}$ The synthetic route that we developed to access (+)- and (-)-clusianone was designed to be amenable to the synthesis of a diverse array of structural analogues, for eventual testing as anti-viral agents. ${ }^{11}$ Herein we describe the initial realization of this objective through the asymmetric total synthesis of four analogues of (+)-clusianone.

For our initial studies on analogue preparation, we choose to focus on two diversity points, namely the C-1 bridgehead position, and the C-3 position. Doing so would allow us to rapidly generate analogues from the common advanced intermediate 8 (Scheme 1), which we had previously ${ }^{6}$ established could be readily prepared with an er of 99:1, via enantioselective ACC ketone $\alpha$-alkylation. ${ }^{7}$ We anticipated that 8 would undergo bridgehead alkylation ${ }^{9 a, c}$ with various alkyl halides to give 7 , and

\footnotetext{
* Corresponding author. email: dcoltart@uh.edu (D. M. Coltart)
}

2009 Elsevier Ltd. All rights reserved.

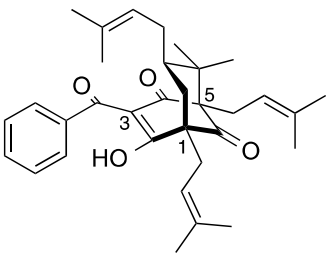

(+)-Clusianone (1)

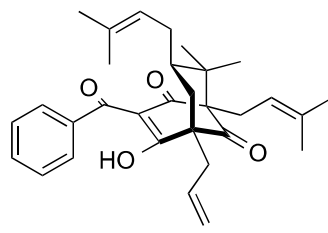

2

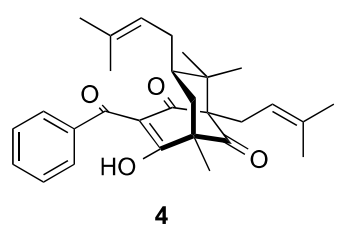

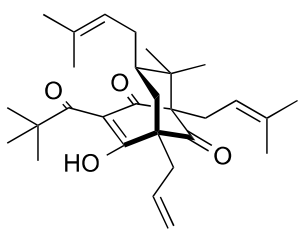

3

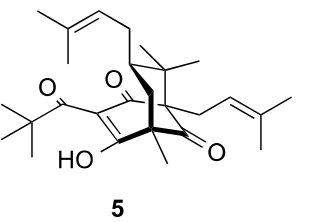

Figure 1. (+)-Clusianone (1) and structural analogues 2-5.

this could then be treated with different acid chlorides to give the desired analogues (6). 


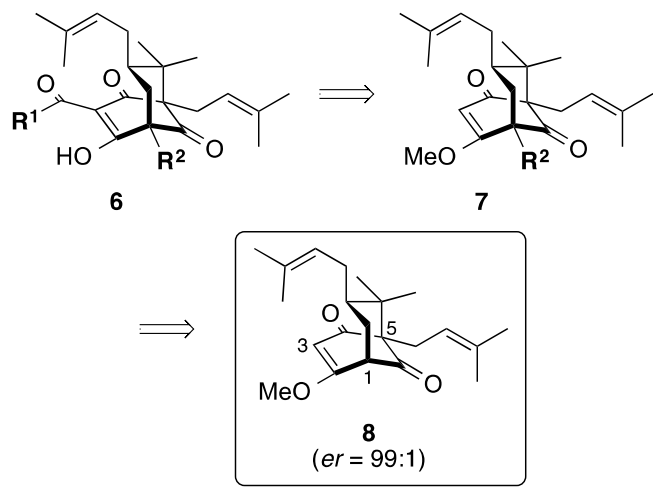

Scheme 1. General approach to C-1 and C-3 analogues from common advanced intermediate $\mathbf{8}$.

The route that we had developed previously ${ }^{6}$ for the preparation of $\mathbf{8}$ had served us well in generating both (+)- and ()-clusianone on a milligram test scale. However, in the context of the present proposed analogue studies we would need access to gram quantities of $\mathbf{8}$, and in this regard our route was untested. Thus, we began our work by repeating our prior synthesis of $\mathbf{8}$, but doing so on a scale that would eventually lead us gram quantities. The route began with the prenylation of 1,3cyclohexadione (9) to give $\mathbf{1 0}$ (Scheme 2). ${ }^{12}$ Conversion of $\mathbf{1 0}$ to $\beta$-chloro enone 11 was achieved using oxalyl chloride, and was followed by reduction to give enone 12. With $\mathbf{1 2}$ in hand, we were positioned to conduct the enantioselective ACC alkylation sequence. During the course of earlier investigations on our ACC monoalkylation method ${ }^{13}$ we found that for ketones possessing at least two substituents at the $\alpha^{\prime}$-position, ACC auxiliary 13 gave extremely high (>98:2) levels of asymmetric induction and excellent yields. Thus, auxiliary $\mathbf{1 3}$ was chosen for use here and was condensed with enone $\mathbf{1 2}$ to generate hydrazone $\mathbf{1 4}$ as a single diastereomer in 95\% yield. Hydrazone 14 was
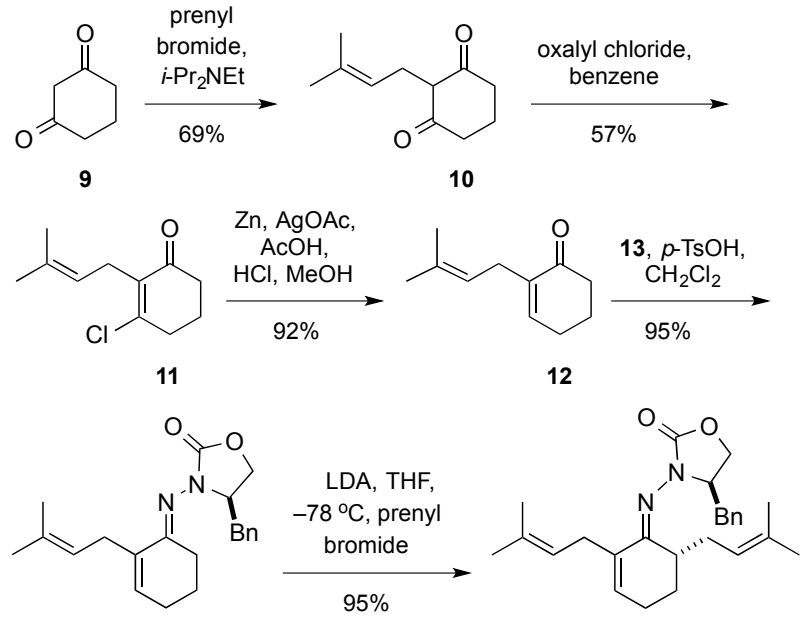

14

15
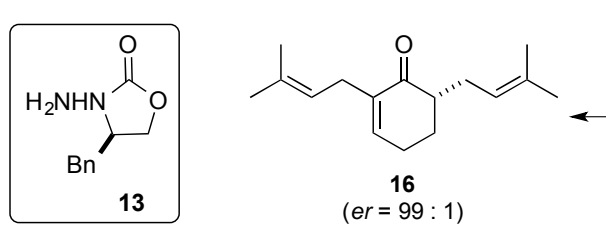

p- $\mathrm{TsOH}$, acetone, $\mathrm{H}_{2} \mathrm{O}$ $80 \%$

Scheme 2. Synthesis of $\mathbf{1 6}$ via enantioselective ACC alkylation.
Tetrahedron

then alkylated in excellent yield by treatment with LDA followed by prenyl bromide. Removal of the auxiliary using $p-\mathrm{TsOH} \cdot \mathrm{H}_{2} \mathrm{O}$ in acetone $/ \mathrm{H}_{2} \mathrm{O}$ produced intermediate 16 with excellent enantioselectivity $(\mathrm{er}=99: 1) .{ }^{14}$
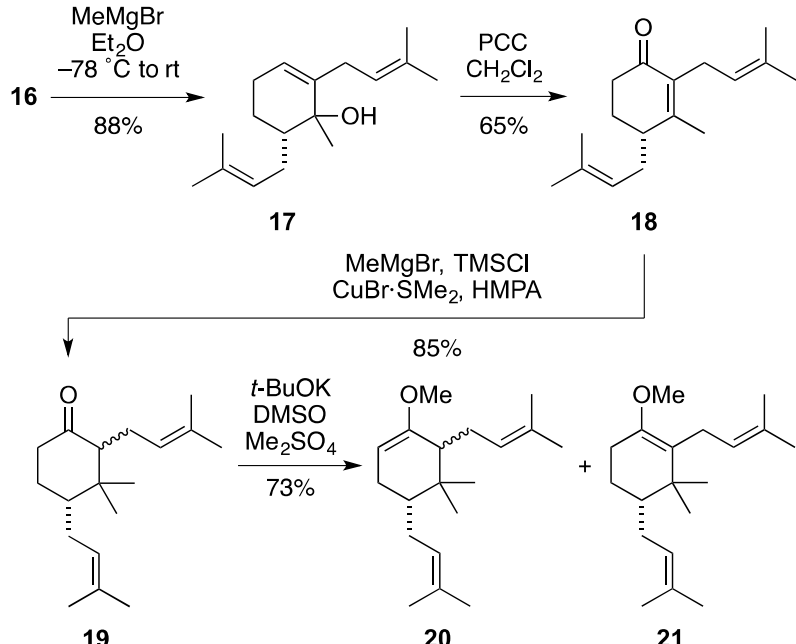

19
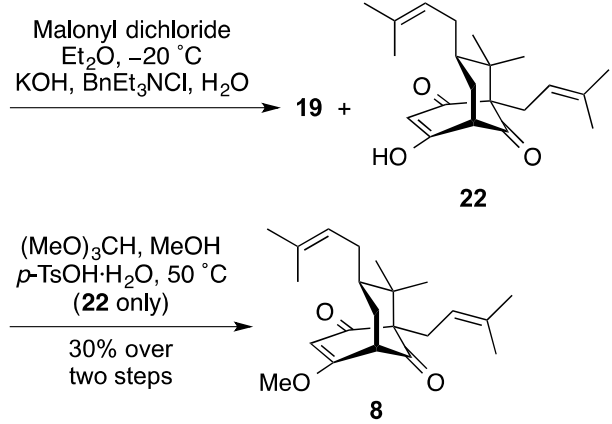

Scheme 3. Synthesis of key intermediate 8 .

Conversion of ketone $\mathbf{1 6}$ to the key advanced intermediate $\mathbf{8}$ began with a methylation, carbonyl transposition sequence. Thiswas achieved by treatment of $\mathbf{1 6}$ with $\mathrm{MeMgBr}$ to form tertiary allylic alcohol $\mathbf{1 7}$ as a mixture of diastereomers (Scheme $3)$. These were used without separation in the Babler-Dauben oxidation ${ }^{15,16}$ to produce enone 18. This was then subjected to conjugate addition by the cuprate obtained from $\mathrm{MeMgBr}$ and $\mathrm{CuBr} \cdot \mathrm{SMe}_{2}$ to establish the geminal dimethyl group, producing ketone 19. Methyl enol ethers 20 and 21 were generated from 19 upon treatement with $t$ - $\mathrm{BuOK}$ and $\mathrm{Me}_{2} \mathrm{SO}_{4}$, setting the stage for an Effenberger cyclization. ${ }^{17}$ Careful acid/base extraction was required following this transformation to separate the desired product (22) from 19, and the latter was recycled to produce more of $\mathbf{2 0}$ and 21. Methylation of crude cyclized product $\mathbf{2 2}$ gave 8 in $30 \%$ yield over the two steps $(71 \%$ based on recovered 19). Gratifyingly, we were able to prepare approximately 2 grams of $\mathbf{8}$ using the above route, confirming its ability to support analogue studies. We anticipate the further direct scale up will also be possible.

Having accessed advanced intermediate $\mathbf{8}$, we were at a divergence point with regard to the synthesis of the four desired analogues (2-5) of (+)-clusianone. Continuation of the synthesis of each of these compounds began with the bridgehead allylation of $\mathbf{8}$, which was achieved by treatment with LDA, followed by allyl bromide. The desired product (23) was obtained in excellent yield from this reaction. In an analogous fashion, methylated compound $\mathbf{2 4}$ was also obtained in excellent yield. 


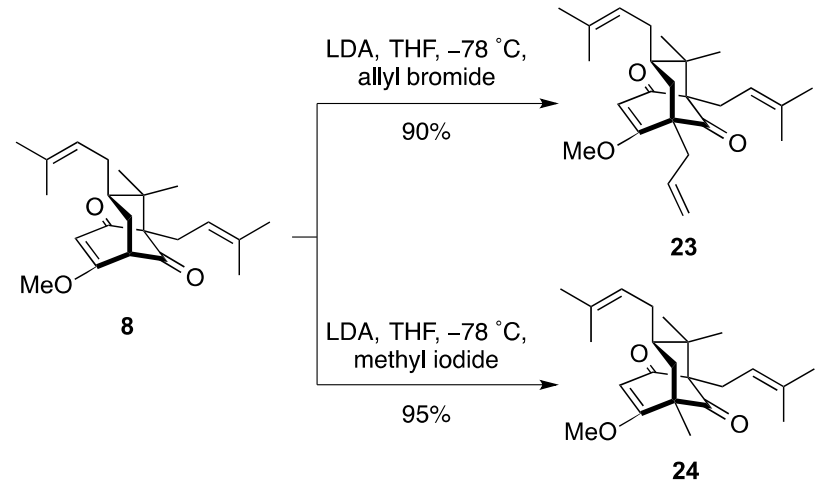

Scheme 4. Bridgehead alkylation of 8 .

Next, both $\mathbf{2 3}$ and $\mathbf{2 4}$ were individually subjected to treatment with both benzoyl chloride and 2,2-dimethylpropanoyl chloride, and the products of those reactions were then hydrolyzed using $\mathrm{LiOH}$ to give the desired analogues 2-4 (Scheme 5). Gratifyingly, in each case the desired compounds were obtained in very good yield over the two step process.

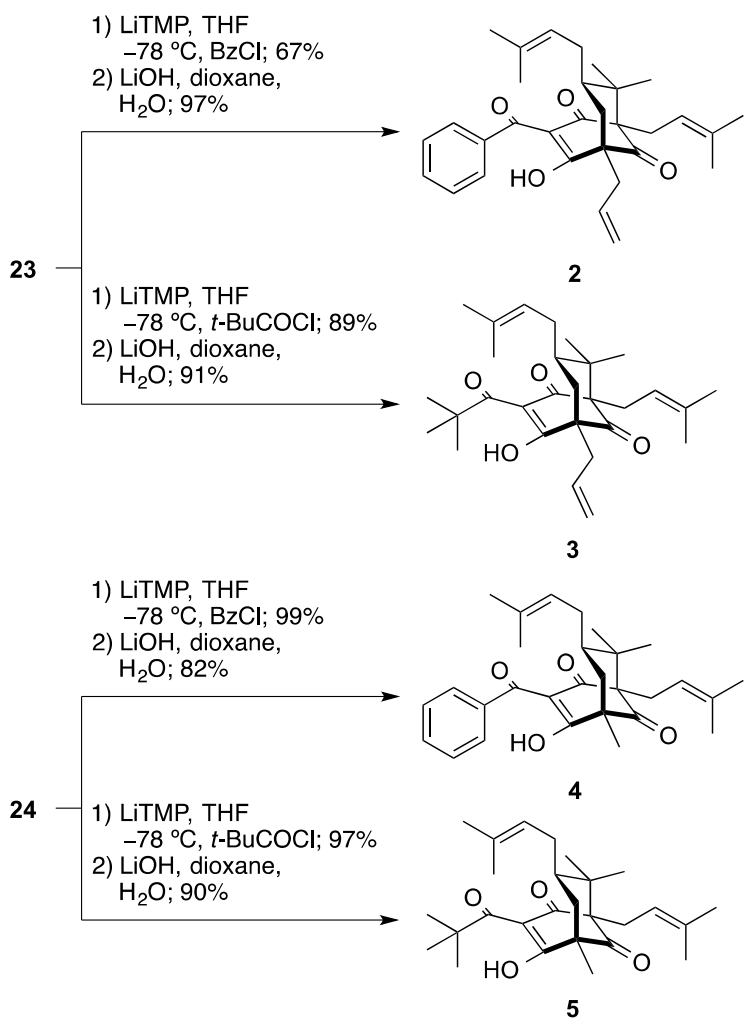

Scheme 5. Acylation of $\mathbf{2 3}$ and $\mathbf{2 4}$.

In conclusion, we have developed an effective gram scale asymmetric synthetic strategy to advanced intermediate $\mathbf{8}$, which, in principle, is amenable to the synthesis of a diverse array of structural analogues of clusianone. As an initial demonstration of this, we have prepared compounds 2-5. A key transformation of this synthetic sequence is a highly enantioselective (er $=99: 1)$ ketone $\alpha$-alkylation sequence that is achieved using our enantioselective ACC $\alpha$-alkylation method. Biological evaluation of compounds $\mathbf{2}-\mathbf{5}$ is underway and will be reported in due course.

\section{Acknowledgments}

We are grateful to the NSF (NSF 1300652) and the University of Houston for support. M.R.G. is grateful for support from the Pharmacological Sciences Training Program at Duke University.

Supplementary data associated with this article can be found, in the online version, at $\mathrm{X}$.

\section{References and notes}

1. (a) Walsh, C. Nature 2006, 406, 775-781; (b) Fisher, J. F.; Meroueh, S. O.; Mobashery, S. Chem. Rev. 2005, 105, 395-424.

2. Strasfeld, L.; Chou, S. Infect. Dis. Clin. N. Am. 2010, 24, 809-833.

3. Ciochina, R.; Grossman, R. B. Chem. Rev. 2006, 106, 3963-3986.

4. Piccinelli, A. L.; Cuesta-Rubio, O.; Chica, M. B.; Mahmood, N.; Pagano, B.; Pavone, M.; Barone, V.; Rastrelli, L. Tetrahedron 2005, 61, 8206-8211.

5. Ito, C.; Itoigawa, M.; Miyamoto, Y.; Onoda, S.; Rao, K. S.; Mukainaka, T.; Tokuda, H.; Nishino, H.; Furukawa, H. J. Nat. Prod. 2003, 66, 206-209.

6. Garnsey, M. R.; Lim, D.; Yost, J. M.; Coltart, D. M. Org. Lett. 2010, 12, 5234-5237.

7. (a) Lim, D.; Coltart, D. M. Angew. Chem., Int. Ed. 2008, 47, 5207. 5210. (b) Krenske, E. H.; Houk, K. N.; Lim, D.; Wengryniuk, S. E.; Coltart, D. M. J. Org. Chem. 2010, 75, 8578-8584. (c) Wengryniuk, S. E.; Lim, D.; Coltart, D. M. J. Am. Chem. Soc. 2011, 133, 8714-8720.

8. Garnsey, M. R.; Matous, J. A.; Kwiek, J. J.; Coltart, D. M. Bioorg. Med. Chem. Lett. 2011, 21, 2406-2409.

9. For previous racemic syntheses of clusianone, see: a) Rodeschini, V.; Ahmad, N. M.; Simpkins, N. S. Org. Lett. 2006, 8, 5283-5285; b) Tsukano, C.; Siegel, D. R.; Danishefsky, S. J. Angew. Chem. 2007, 119, 8996-9000; c) Ahmad, N. M.; Rodeschini, V.; Simpkins, N. S.; Ward, S. E.; Blake, A. J. J. Org. Chem. 2007, 72, 4803-4815; d) Qi, J.; Porco, Jr. J. A. J. Am. Chem. Soc. 2007, 129, 12682-12683; e) Nuhant, P.; David, M.; Pouplin, T.; Delpech, B.; Marazano, C. Org. Lett. 2007, 9, 287-289; f) Uwamori, M.; Nakada, M. Nat. Prod. Commun. 2013, 66, 141-145.

10. For previous asymmetric syntheses of clusianone, see: a) Rodeschini, V.; Simpkins, N. S.; Wilson, C. J. Org. Chem. 2007, 72, 4265-4267; b) Garnsey, M. R.; Lim, D.; Yost, J. M.; Coltart, D. M. Org. Lett. 2010, 12, 5234-5237; c) Garnsey, M. R.; Matous, J. A.; Kwiek, J. J.; Coltart, D. M. Bioorg. Med. Chem. Lett. 2011, 21, 2406-2409; Boyce, J. H.; Porco, J. A. Jr. Angew. Chem. Int. Ed. 2014, 53, 7832-7837.

11. Simple modifications to PPAP ring structures have been shown to have a large effect on their biological activity. See, for example, reference 3 .

12. Clark, R. D.; Heathcock, C. H. J. Org. Chem. 1976, 41, 636-643.

13. Reference 6,8, and unpublished results.

14. Established by HPLC using a chiral, non-racemic stationary phase by comparison to an independently prepared racemic sample of $\mathbf{1 6}$ under conditions that gave baseline separation of its enantiomers (see reference 6 for details).

15. Dauben, W. G.; Michno, D. M. J. Org. Chem. 1977, 42, 682-685.

16. Babler, J. H.; Coghlan, M. J. Synthetic Commun. 1976, 6, 469474.

17. Schonwalder, K. H.; Kollat, P.; Stezowski, J. J.; Effenberger, F. Chem. Ber. 1984, 117, 3280-3296. 


\section{Graphical Abstract}

\section{Asymmetric Synthesis of Structural}

Analogues of $(+)$-Clusianone via

Enantioselective ACC Alkylation

Leave this area blank for abstract info.

Michelle R. Garnsey, Maulen M. Uteuliyev and Don M. Coltart

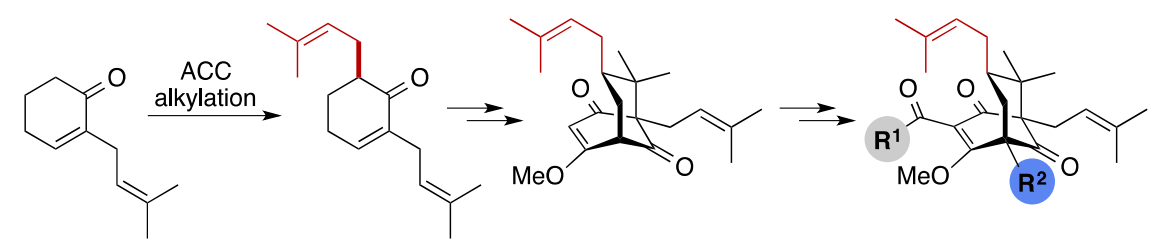

